\title{
HUBUNGAN KECERDASAN EMOSIONAL DENGAN HASIL BELAJAR BIOLOGI SISWA KELAS X MIA MAN 3 MEDAN T.P. 2017/2018
}

\author{
Nur Aisyah Putri Rambe, Uswatun Hasanah, Neneng Chairunnisa \\ Program Studi Pendidikan Biologi, FMIPA, Universitas Negeri Medan, Medan \\ Jl. Williem Iskandar Psr. V Medan Estate, Medan, Indonesia, 20221 \\ E-mail : putrirambe95@gmail.com
}

\begin{abstract}
ABSTRAK
Penelitian ini bertujuan untuk mengetahui hubungan kecerdasan emosional dengan hasil belajar Biologi siswa kelas X MIA MAN 3 Medan Tahun Pembelajaran 2017/2018. Populasi dalam penelitian ini adalah seluruh siswa-siswi kelas X MIA MAN 3 Medan yang terdiri dari 5 kelas. Sampel yang digunakan 2 kelas dari 5 kelas dengan jumlah 81 siswa. Untuk memperoleh data kecerdasan emosional digunakan angket yang telah divalidkan oleh dosen validator. Sedangkan hasil belajar biologi diambil dari nilai ulagan harian siswa yang diperoleh dari guru bidang studi Biologi. Data yang diperoleh dicari nilai rata-rata, standar deviasi, dan uji persyaratan datanya. Kecerdasan emosional siswa memiliki $\bar{X} \pm$ SD sebesar 91,30 $\pm 9,26$, sedangkan hasil belajar biologi siswa sebesar $78,37 \pm 8,73$. Dari hasil analisis statistik diketahui hubungan kecerdasan emosional dengan hasil belajar biologi siswa memiliki arah persamaan regresi yang linear dan memiliki hubungan yang berarti, hal ini dapat kita lihat dari koefisien korelasi yang tinggi yaitu sebesar 0,871 dan besarnya konstribusi kecerdasan emosional terhadap hasil belajar biologi siswa yaitu sebesar 75,69\%. Artinya kecerdasan emosional memiliki hubungan yang positif dengan hasil belajar Biologi siswa kelas X MIA MAN 3 Medan Tahun Pembelajaran 2017/2018.
\end{abstract}

Kata kunci : Kecerdasan emosional, hasil belajar.

\section{ABSTRACT}

his study aims to determine the relationship of emotional intelligence with learning outcomes Biology X class students MIA MAN 3 Medan Year Learning 2017/2018. The population in this study is all students of class X MIA MAN 3 Medan consisting of 5 classes. Sample used 2 classes from 5 classes with total 81 students. To obtain the data of emotional intelligence used questionnaire that has been validated by a validator lecturer. While the results of biology learning taken from the value of daily student ulagan obtained from teachers of Biology study. The data obtained are searched for the mean value, standard deviation, and test the data requirements. Emotional intelligence of students has \pm SD of $91.30 \pm 9.26$, while the student's biology learning outcome is $78.37 \pm 8.73$. From the results of statistical analysis known the relationship of emotional intelligence with the results of biology students have a linear regression equation and have a meaningful relationship, this we can see from the high correlation coefficient of 0.871 and the amount of emotional intelligence contribution to student biology learning results of equal $75.69 \%$. This means that emotional intelligence has a positive relationship with learning outcomes Biology X class student MIA MAN 3 Medan Year Learning 2017/2018.

Keywords: Emotional intelligence, learning outcomes.

\section{PENDAHULUAN}

Pendidikan adalah suatu usaha untuk kegiatan yang dijalankan dengan sengaja, teratur dan berencana dengan maksud mengubah atau mengembangkan perilaku yang diinginkan. Sekolah sebagai lembaga formal merupakan sarana dalam rangka pencapaian tujuan pendidikan tersebut. Menurut Silalahi dan Hasruddin (2016:
54) melalui sekolah, siswa belajar berbagai macam hal yang pada akhirnya bertujuan meningkatkan hasil belajar. Hasil belajar adalah tingkat kemampuan anak didik dalam menerima suatu jenis pelajaran yang diberikan oleh guru dalam kegiatan belajar mengajar.

Menurut Hamalik (2013: 27) belajar adalah modifikasi atau memperteguh kelakuan melalui 
pengalaman, menurut pengertian ini, belajar merupakan suatu proses, suatu kegiatan dan bukan suatu hasil atau tujuan. Belajar bukan hanya mengingat, akan tetapi lebih luas dari itu, yakni mengalami. Hasil belajar bukan suatu penguasaan hasil latihan melainkan pengubahan kelakuan.

Proses pembelajaran yang diikuti selama menuntut ilmu di lembaga pendidikan formal secara langsung ataupun tidak langsung akan melatih kecerdasan emosional. Emotional Quotient (EQ) atau yang biasa kita sebut dengan kecerdasan emosional itu meliputi pengenalan diri, pengendalian diri, motivasi, empati, dan keterampilan sosial. Walaupun pada kenyataannya, sistem pendidikan masih menekankan Intelligence Quotient (IQ) sebagai simbol kecerdasan.

Berdasarkan penelitian yang telah dilakukan oleh Gusniwati (2015: 27) dalam proses belajar siswa, IQ dan EQ sangat diperlukan. IQ tidak dapat berfungsi baik tanpa partisipasi penghayatan emosional terhadap mata pelajaran yang disampaikan di sekolah. Namun, biasanya kedua inteligensi itu saling melengkapi. Keseimbangan antara IQ dan EQ merupakan kunci keberhasilan belajar siswa di sekolah. Pendidikan di sekolah bukan hanya perlu mengembangkan rational intelligence, yaitu model pemahaman yang lazimnya dipahami siswa saja, melainkan juga perlu mengembangkan emotional intelligence siswa.

Hasil penelitian Goleman dalam Defila dan Saehana (2004: 29) menyatakan bahwa kecerdasan intelektual (IQ) hanya menyumbang $20 \%$ bagi kesuksesan, sedangkan yang lainnya adalah sumbangan faktor kekuatan - kekuatan lain, di antaranya adalah kecerdasan emosional (EQ) yakni kemampuan mengembangkan diri, kemampuan mengembangkan empati, dan kemampuan mengembangkan kecakapan dalam membina hubungan dengan orang lain.

Berdasarkan wawancara yang telah dilakukan peneliti dengan guru Biologi kelas $X$ Matematika dan IImu Alam (MIA) di Madrasah Aliah Negeri (MAN) 3 Medan pada Februari 2017, hasil belajar Biologi siswa belum dapat dikatakan memuaskan. Hal ini dapat dilihat dari hasil belajar Biologi sebagian besar siswa belum dapat mencapai Kriteria Ketuntasan Minimal (KKM)
Biologi di kelas X MIA MAN 3 Medan adalah 80 . Saat penulis melakukan wawancara dengan beberapa siswa kelas X MIA di MAN 3 Medan, para siswa memiliki motivasi yang rendah dalam mengikuti pelajaran biologi, hal ini disebabkan kurangnya dukungan dari orang tua maupun lingkungan sekitar siswa. Menurut para siswa materi pelajaran biologi menuntut banyak hafalan dan banyak menggunakan bahasa latin yang sudah merupakan suatu keharusan. Hal ini jugalah sebagai salah satu penyebab timbulnya kejenuhan dalam mempelajari biologi.

\section{METODE PENELITIAN}

Penelitian ini dilaksanakan di MAN 3 Medan yang beralamat di Jl. Pertahanan No. 99, Kel. Timbang Deli, Kec. Medan Amplas, Kota Medan, Prov. Sumatera Utara. Populasi dalam penelitian ini adalah seluruh siswa kelas $X$ MIA MAN 3 Medan yang terdiri atas 5 kelas dengan jumlah siswa keseluruhan sebanyak 214 orang. Sampel yang digunakan dalam penelitian ini diambil dengan tehnik random sampling. Sampel yang diambil sebanyak 2 kelas yaitu kelas X MIA 1 dengan jumlah siswa sebanyak 41 orang dan kelas $X$ MIA 4 dengan jumlah siswa sebanyak 40 orang.

Instrumen dalam penelitian ini adalah angket kecerdasan emosional siswa. Hasil belajar diambil dari dokumen hasil belajar biologi siswa yang diperoleh dari guru bidang studi biologi. Jenis penelitian ini adalah penelitian deskriptif yaitu penelitian yang mendeskripsikan hubungan kecerdasan emosional dengan hasil belajar biologi siswa. Teknik analisis data dimulai dengan mentabulasi data, mencari nilai rata-rata dan standar deviasi, kemudian melakukan uji prasyarat data dimulai dari uji normalitas, uji homogenitas, uji linearitas, uji hipotesis, dan menghitung koefisien korelasi product moment.

\section{HASIL PENELITIAN}

Berdasarkan data angket hasil penelitian mengenai kecerdasan emosional terhadap 81 responden yang terdiri dari dua kelas, yaitu kelas $X$ MIA 1 dan kelas X MIA 4, diperoleh skor tertinggi 111 dan skor terendah 71 , dengan rata-rata $(\mathrm{M})=$ 91,30 dan standar deviasi $(S D)=9,26$. Data hasil belajar biologi siswa diperoleh dari guru bidang 
studi biologi, dengan skor tertinggi 88 dan skor terendah 60 , dengan rata-rata $(M)=78,37$ dan standar deviasi $(S D)=8,73$.

Untuk mengetahui apakah kecerdasan emosional memiliki hubungan dengan hasil belajar biologi siswa dapat dilakukan dengan uji koefisien korelasi. Dari hasil uji koefisien korelasi diperoleh harga koefisien korelasi hubungan kecerdasan emosional dengan hasil belajar biologi siswa sebesar 0,871. Hasil uji hipotesis dengan uji t juga menunjukkan $t_{\text {hitung }}(15,684)>t_{\text {tabel }}(1,999)$ hal ini membuktikan bahwa terdapat hubungan yang signifikan antara kecerdasan emosional dengan hasil belajar biologi siswa. Selanjutnya untuk menentukan besarnya konstribusi kecerdasan emosional dengan hasil belajar, dilakukan dengan menguadratkan koefisien korelasi dan dikalikan 100 , sehingga hasil yang didapat sebesar $75,69 \%$, yang artinya variabel kecerdasan emosional memberikan konstribusi sebesar 75,69\% terhadap hasil belajar biologi siswa kelas X MIA MAN 3 Medan T.P. 2017/2018. Sementara sisanya ditentukan oleh faktor-faktor lainnya.

Selanjutnya untuk mengetahui kedua variabel linear atau tidak, digunakan uji regresi linear. Hasil uji regresi antara dua variabel dengan nilai signifikansi 0,05. Berdasarkan syarat statistik uji $F$ Bila $F_{\text {hitung }}>F_{\text {tabel }}$ pada taraf signifikan 0,05 maka disimpulkan bahwa garis regresi linear. Dari perhitungan yang telah dilakukan diketahui koefisien $a=3,34$ dan koefisien $b=0,82$. Dengan diperolehnya harga koefisien a dan $b$, maka bentuk persamaan regresi $Y$ atas $X$ menjadi $\hat{Y}=0,82 x+$ 3,34 , yang artinya perubahan $Y$ atas $X$ sebesar 0,82 pada konstanta 3,34 . Bentuk persamaan regresi linear yang telah diperoleh dapat dilihat pada Gambar 1. Perhitungan untuk uji kelinearan dan keberartian persamaan regresi dapat disusun dalam Tabel 1.

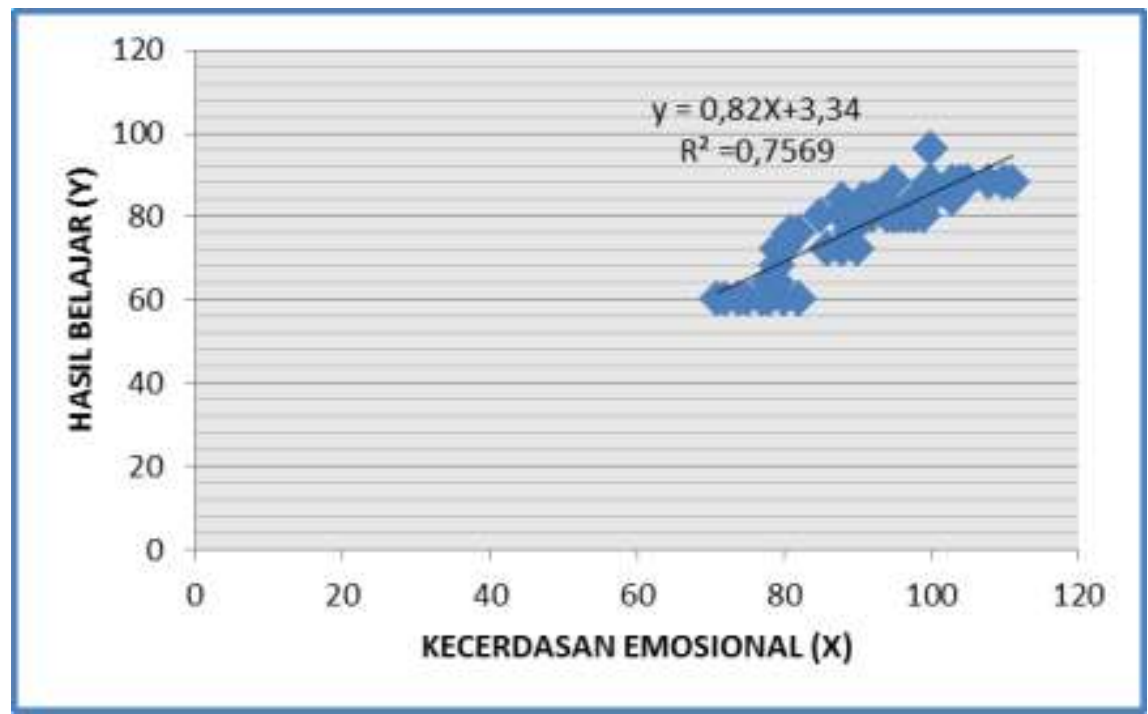

Gambar 1. Diagram Pencar Hubungan Kecerdasan Emosional Dengan Hasil Belajar Biologi Siswa

Tabel 1. Analisis Varians Untuk Uji Kelinearan Dan Keberartian Persamaan Regresi

\begin{tabular}{ccccc}
\hline Sumberesi Varian & DK & JK & KT & F \\
\hline Total & 81 & 503600 & 503600 & - \\
Regresi (a) & 1 & 497495,11 & 497495,12 & 247,37 \\
Regresi (b/a) & 1 & 4625,62 & 4625,62 & \\
Residu & 79 & 1479,3 & 18,7 & 1,36 \\
Tuna cocok & 29 & 481,862 & 22,72 & 16,71 \\
Kekeliruan & 50 & 818,915 & & \\
\hline
\end{tabular}


Sehingga untuk uji kelinearan, didapat $F=1,36$ dan ini lebih kecil dari 1,70. Jadi dapat dinyatakan bahwa model regresi $Y$ atas $X$ diperoleh $F_{\text {tabel }}$ dengan $\mathrm{dk}(\mathrm{n}-2)=\mathrm{F}_{(1,79)}$ adalah 3,98. Dengan demikian diketahui bahwa $F_{\text {hitung }}(247,37)>F_{\text {tabel }}(3,98)$, maka dapat disimpulkan bahwa regresi $Y$ atas $X$ berarti pada taraf signifikan $\alpha=0,05$.

\section{PEMBAHASAN}

Kecerdasan emosional adalah kemampuan seseorang untuk menerima, mengelola, memotivasi serta mengontorl emosinya sendiri dan orang lain di sekitarnya. Goleman dalam Defila dan Saehana (2004:29) menyatakan kecerdasan bila tidak disertai dengan pengolahan emosi yang baik tidak akan menghasilkan kesuksesan seseorang dalam hidupnya. Peranan kecerdasan akademik (IQ) menentukan kesuksesan seseorang sebesar 20\% sedangkan $80 \%$ adalah sumbangan dari faktor lain, di antaranya adalah kecerdasan emosional. Hal ini disebabkan karena kecerdasan akademik tidak memberikan kesiapan untuk menghadapi gejolak yang ditimbulkan oleh kesulitan hidup.

Hasil analisis data menunjukkan bahwa terdapat hubungan yang positif antara kecerdasan emosional dengan hasil belajar biologi siswa yang ditunjukkan melalui koefisien korelasi sebesar 0,871 yang tergolong tinggi dengan persentase konstribusi sebesar $75,69 \%$. Hasil penelitian ini menunjukkan bahwa kecerdasan emosional berpengaruh 75,69\% terhadap hasil belajar biologi siswa kelas X MIA MAN 3 Medan. Hasil penelitian ini sejalan dengan hasil penelitian sebelumnya yang dilakukan Daud (2012:253) bahwa terdapat pengaruh yang positif antar kecerdasan emosional terhadap hasil belajar biologi siswa dengan konstribusi sebesar $47,4 \%$, namun hasil penelitian yang dilakukan oleh Daut memiliki pengaruh yang lebih kecil dibanding hasil penelitian ini.

Menurut Nggermanto (2001: 100) indikator kecerdasan emosional meliputi: (1) kesadaran diri, (2) pengaturan diri, (3) motivasi, (4) empati, (5) keterampilan sosial. Dilihat dari besarnya konstribusi masing-masing indikator maka konstribusi paling besar terhadap hasil belajar di kelas X MIA MAN 3 Medan Tahun
Pembelajaran 2017/2018 adalah empati sebesar $21,5 \%$. Sedangkan besar konstribusi indikator lainnya yaitu, kesadaran diri sebesar 19,5\%, pengaturan diri sebesar $18 \%$, motivasi sebesar $20 \%$, dan keterampilan sosial sebesar $21 \%$. Sedangkan dalam penelitian yang dilakukan Lestari (2015: 37) indikator motivasi-lah yang memiliki nilai terbesar yakni $26,01 \%$ sedangkan indikator yang memiliki nilai terkecil adalah empati yakni $8,46 \%$. Hal ini didasarkan pada individu masingmasing siswa, karena tidak semua siswa memiliki empati, motivasi atau-pun keterampilan sosial yang sama besarnya. Sebagian siswa justru memiliki kesadaran diri dan pengaturan diri yang lebih tinggi.

Dari perhitungan indeks determinasi, kecerdasan emosional memiliki peran penting dan berpengaruh terhadap hasil belajar. Hal ini dapat dilihat dari faktor-faktor antara kecerdasan emosi dan hasil belajar. Dalam kecerdasan emosional terdapat 5 faktor yang dikemukakan oleh Goleman (2016:58) yaitu, mengenali emosi diri, mengolah emosi, memotivasi diri sendiri, mengenali emosi orang lain, dan membina hubungan dengan orang lain. Sedangkan hasil belajar menurut Slameto (2006: 112) memiliki dua faktor yaitu faktor internal dan faktor eksternal. Lima faktor kecerdasan emosi tersebut merupakan suatu kemampuan seseorang dalam memahami emosi diri. Dalam kecerdasan emosi seseorang mampu mengendalikan diri, memiliki kesadaran diri, mampu melepaskan diri dari keterpurukan serta mampu bersosialisasi dengan orang lain, dan memiliki motivasi diri. Hal ini sangant berhubungan dengan faktor-faktor hasil belajar, karena untuk memperoleh hasil belajar yang optimal seseorang perlu memiliki intelegensi, perhatian, minat, bakat, motivasi, kematangan dan kesiapan, mampu mengatasi kelelahan, bisa mengatasi kecemasan, mampu bergaul dengan orang lain yang merupakan bagian dari kecerdasan emosional.

Berdasarkan hasil analisis data yang telah diuraikan maka dapat kita lihat konstribusi dari kecerdasan emosional sebesar 75,69\% sangat memegang peran penting terhadap keberhasilan para siswa dalam kegiatan belajarnya. Menurut Goleman dalam penelitian Djuniarto (2014: 5) menyatakan individu yang memiliki tingkat 
kecerdasan emosional tinggi memiliki lebih besar kemungkinan untuk merasa bahagia dan berhasil dalam hidupnya, dan ditandai juga dengan adanya kemampuan untuk menguasai pikiran dan emosinya yang dapat mendorong produktifitas mereka. Jika berdasarkan hasil belajar subjek berada pada kategori sedang, hal tersebut mungkin disebabkan oleh faktor internal dan faktor eksternal yang kurang mendukung bagi peningkatan hasil belajar siswa seperti kelengkapan fasilitas belajar, bahan pelajaran, masalah pribadi dan keluarga, dan kesehatan siswa. Adapun hasil yang didapat mencapai angka 75,69\% dapat disebabkan antara lain faktor kejujuran dalam mengisi angket, namun faktor lain yang juga dapat mempengaruhi adalah suasana hati dan emosi pada saat mengisi angket dan ketidak beranian siswa menjawab angket dengan jujur.

\section{SIMPULAN}

Kecerdasan emosional dengan hasil belajar biologi siswa kelas X MIA MAN 3 Medan memiliki hubungan yang positif dengan nilai koefisien korelasi sebesar 0,871. Kecerdasan emosional memberikan konstribusi sebesar 75,69\% terhadap hasil belajar biologi siswa kelas X MIA MAN 3 Medan Tahun Pembelajaran 2017/2018.

\section{DAFTAR PUSTAKA}

Ardana, I, C. Ardana, A. dan Elizabeth, S, D., (2013), Kecerdasan Intelektual, Kecerdasan Emosional, Kecerdasan Spiritual, Dan Kesehatan Fisik Untuk Memprediksi Prestasi Belajar Mahasiswa Akuntansi, Jurnal Akuntansi, Vol. XVII, No, 03. Hal. 445, Fakultas Ekonomi Universitas Tarumanegara, Jakarta.

Daud, F., (2012), Pengaruh Kecerdasan Emosional (EQ) Dan Motivasi Belajar Terhadap Hasil Belajar Biologi Siswa SMA 3 Negeri Kota Palopo, Jurnal Pendidikan Dan Pembelajaran, Vol. 9, No. 2, Hal. 245, Pendidikan Biologi PPS UNM, Makasar.

Defila, M. dan Saehana, S., (2004), Hubungan Kecerdasan Emosional Dengan Hasil Belajar IPA Siswa SMP Negeri 1 Palu, Jurnal Pendidikan Fisika Tadulako (JPFT), Vol. 2 No. 2, Hal. 30, Universitas Tadulako, Sulawesi Tengah.
Djuniarto, E. Dan Sari, A, P., (2014),. Hubungan Antara Kecerdasan Emosional Dengan Prestasi Akademik Mahasiswa Psikologi Tingkat Satu Universitas Gunadarma, Jurnal Pendidikan, Vol. 3. No. 1, Hal. 5, Universitas Gunadarma.

Goleman, D., (2016), Kecerdasan Emosional. PT Gramedia Pustaka Utama, Jakarta.

Gusniwati, M., (2015), Pengaruh Kecerdasan Emosional Dan Minat Belajar Terhadap Penguasaan Konsep Matematika Siswa Sman Di Kecamatan Kebon Jeruk, Jurnal Formatif, Vol.1. No. 1, Hal. 30,Universitas Indraprasta.

Hamalik, O., (2001), Proses Belajar Mengajar, Bumi Aksara, Jakarta.

Ngermanto, A., (2002), Quantum Quotient (Kecerdasan Kuantum), Yayasan Nuansa Cendikia, Bandung.

Silalahi, R, R., dan Hasruddin., (2016), Perbandingan Model Pembelajaran Kooperatif Tipe NHT Dengan STAD Terhadap Hasil Belajar Siswa Terhadap Materi Sistem Pencernaan Manusiam Jurnal Pelita Pendidikan, Vol.4, No. 2, Hal 54, Universitas Negeri Medan.

Slameto., (2012), Belajar dan Faktor-Faktor yang Mempengaruhinya, PT. Rineka Cipta, Jakarta.

Uno, B. H., (2008), Orientasi Baru Dalam Psikologi Pembelajaran, Bumi Aksara, Jakarta. 